\title{
Medical care of patients with disorders of aromatic amino acid metabolism: a report based on the Polish National Health Fund data records
} Opieka medyczna nad chorymi z zaburzeniami przemiany aminokwasów aromatycznych na podstawie danych sprawozdawczych Narodowego Funduszu Zdrowia

\author{
${ }^{1}$ Agnieszka Szypowska, 2,3Edward Franek, ${ }^{4}$ Władysław Grzeszczak, ${ }^{5}$ Winicjusz Filipow, \\ ${ }^{3}$ Mariusz Zięba, ${ }^{3}$ Paweł Kabicz, ${ }^{3}$ Barbara Więckowska, ${ }^{6}$ Jolanta Sykut-Cegielska, ${ }^{7}$ Joanna Taybert
}

${ }^{1}$ Department of Paediatrics, Medical University of Warsaw, Poland

${ }^{2}$ Department of Internal Diseases, Endocrinology and Diabetes, Ministry of Internal Affairs Central Teaching Hospital, Warsaw, Poland

${ }^{3}$ Analyses and Strategies Department Ministry of Health, Warsaw, Poland

${ }^{4}$ Department of Internal Diseases, Diabetes and Nephrology, Silesian Medical University, Poland

${ }^{5}$ Research and Development Division for Metabolic Disorders at Diabetica company

${ }^{6}$ Department of Inborn Errors of Metabolism and Paediatrics, Institute of Mother and Child, Warsaw, Poland

${ }^{7}$ Metabolic Disorders Clinic, The Institute of Mother and Child, Warsaw, Poland

The present analysis has been prepared as part of the mapping of health needs in metabolic disorders,

http://www.mapypotrzebzdrowotnych.mz.gov.pl/

\begin{abstract}
Introduction: Patients with disorders of aromatic amino acid metabolism are a heterogeneous group. They vary in morbidity and medical care requirements. Polish newborn screening program allows for quick diagnosis of some inborn errors of metabolism (such as classical phenylketonuria, mild hyperphenylalaninemias, tyrosinemia type 1 and tyrosinemia type 2) and subsequent immediate treatment. The aim of the study: To evaluate the effect of the Polish public healthcare system in terms of management and access to health care services for children and adults with disorders of aromatic amino acid metabolism.

Material and methods: The analysis was based on the National Health Fund (NFZ) reporting data for 2009-2015. The analysis included patients with disorders of aromatic amino acid metabolism converting ICD-10 coding according to the International Classification of Diseases. The analysis covered patients with codes E70, E70.0, E70.1, E70.2, E70.3, E70.8, E70.9. The analysis was prepared as part of the mapping of health needs in metabolic diseases, http://www.mapypotrzebzdrowotnych.mz.gov.pl/.

Results: In 2009-2015, 4090 patients with disorders of aromatic amino acid metabolism were registered in the NFZ system. The largest number of patients were hospitalized and registered in outpatient specialistic care (AOS) in the first year of life. After the second year of life, the number of hospitalized patients was almost zero, and the number of children ( $<18$ years) with AOS according to age was stable. After the 18 years of age the number of patients in the AOS gradually decreased. The population of patients aged 0-28 years accounted for $99 \%$ of all cases, after 28 years of age were only one percent of the total population. There were 95 deaths, the average age of death was 77 years. In the whole study group the highest number of deaths was recorded after 70 years of age, $21 \%$ of all deaths were reported in both working-age patients children ( 2 deaths). Patients with classical phenylketonuria were the most commonly reported in the AOS. 22\% of patients were coded with ICD-10 as E70 without extension.

Conclusions: Children aged 0-18 years with disorders of amino acid metabolism had full access to a well-organized specialized medical care system in Poland. In contrast, care for adult patients with the disorders was limited. It is necessary to properly code the disease using ICD-10 extension codes in order to avoid inconsistency in data reporting or misdiagnosis.
\end{abstract}

Key words:

inborn errors of metabolism, aromatic amino acids, medical care, phenylketonuria. 


\section{Streszczenie}

Wprowadzenie: Pacjenci z zaburzeniami przemiany aminokwasów aromatycznych stanowią niejednorodną grupę. Różnią się chorobowością oraz wymaganiami dotyczącymi opieki medycznej. Ogólnopolski program badań przesiewowych noworodków umożliwia szybkie rozpoznanie chorób z tej grupy, w tym klasycznej fenyloketonurii, łagodnych hiperfenyloalaninemii oraz tyrozynemii typu 1 i tyrozynemii typu 2, z następowym natychmiastowym wdrożeniem leczenia.

Cel pracy: Ocena działania polskiego systemu opieki publicznej w aspekcie organizacji i dostępu do świadczeń dla dzieci i dorosłych z zaburzeniami przemiany aminokwasów aromatycznych.

Materiał i metody: Analizę przeprowadzono na podstawie danych sprawozdawczych Narodowego Funduszu Zdrowia (NFZ) w latach 2009-2015. Do analizy włączono pacjentów z zaburzeniami przemiany aminokwasów aromatycznych kodowanych kodami ICD-10 według Międzynarodowej Klasyfikacji Chorób i Problemów Zdrowotnych, analizą objęto pacjentów z kodami: E70, E70.0, E70.1, E70.2, E70.3, E70.8, E70.9. Przeprowadzona analiza została przygotowana w ramach opracowania dotyczącego map potrzeb zdrowotnych w zakresie chorób metabolicznych, http://www.mapypotrzebzdrowotnych.mz.gov.pl/.

Wyniki: W latach 2009-2015 zarejestrowano w systemie NFZ 4090 pacjentów z zaburzeniami przemiany aminokwasów aromatycznych. Największa liczba pacjentów była hospitalizowana oraz objęta ambulatoryjną opieką specjalistyczną (AOS) w pierwszym roku życia. Po 2. roku życia liczba pacjentów hospitalizowanych była bliska zeru. Liczba dzieci (< 18. roku życia) wykazywanych w AOS w zależności od wieku utrzymywała się na stałym poziomie, po 18. roku życia liczba pacjentów stopniowo się zmniejszała. Populacja chorych w wieku 0-28 lat stanowiła 99\% wszystkich przypadków, pacjenci po 28. roku życia stanowili tylko jeden procent całej badanej populacji. Stwierdzono 95 zgonów, średni wiek zgonu wynosił 77 lat. W całej badanej grupie najwięcej zgonów zanotowano po 70. roku życia, $21 \%$ wszystkich zgonów stwierdzono u pacjentów w wieku produkcyjnym oraz dzieci (2 zgony). W AOS najczęściej wykazywano pacjentów z klasyczną fenyloketonurią; 22\% pacjentów zakodowano kodem bez rozszerzenia E70.

Wnioski: Dzieci (0-18 lat) z zaburzeniami metabolizmu aminokwasów aromatycznych były objęte od urodzenia specjalistyczną opieką medyczną. Stwierdzono niedostateczną opiekę nad pacjentami dorosłymi z tymi schorzeniami. W celu uniknięcia błędów w raportowaniu danych konieczne jest właściwe kodowanie jednostek chorobowych z zastosowaniem szczegółowych kodów z rozszerzeniem wg klasyfikacji ICD-10.

\section{Słowa kluczowe:}

wrodzone wady metabolizmu, aminokwasy aromatyczne, opieka medyczna, fenyloketonuria.

\section{Introduction}

The disorders of aromatic amino-acid metabolism, coded as E70 according to the $10^{\text {th }}$ edition of the International Statistical Classification of Diseases and Related Health Problems (ICD-10), are a heterogenous group of genetic metabolic diseases (referred to - in contrast to multifactorial acquired metabolic disorders - as inborn errors of metabolism). They include, among other conditions, classical phenylketonuria, other hyperphenylalaninaemias, disorders of tyrosine metabolism (alcaptonuria, tyrosinaemia) and albinism. Some of these diagnoses require treatment from birth, others (considered to be mild) do not require any treatment at all, while still others require only limited treatment.

Among the diseases in this group, classical phenylketonuria, caused by phenylalanine hydroxylase deficit, is the most common. The clinical course of classic phenylketonuria is insidious. If left untreated, the disease damages the central nervous system, leading to intellectual disability and various neurological problems $[1,2]$. A rapid diagnosis and treatment are of key importance for the child's development [3-5].

Type 1 tyrosinaemia (tyrosinaemia I) is an ultrarare disease characterised by fumarylacetoacetate hydrolase deficiency. Acute, subacute and chronic forms are distinguished. Acute type 1 tyrosinaemia, which is the most common, has its onset in infancy and manifests with liver dysfunction that progresses to liver failure, renal injury and, in some cases, neurological crises resembling acute porphyria. In untreated patients, this form of type 1 tyrosinaemia, if diagnosed by 2 months of age, is characterised by a 2 -year survival rate of only $29 \%$ [6]. In addition, untreated patients often develop hepatocellular carcinoma

Alcaptonuria is another condition caused by defective phenylalanine and tyrosine metabolism. These patients are deficient for homogentisate 1,2-dioxygenase. During childhood the only sign (often overlooked nowadays) is the dark staining of nappies left to dry in the air. Deposition of homogentisic acid in tissues causes their bluish-black discolouration (the socalled ochronosis). In adulthood, degenerative changes of the vertebral column and various joints are characteristic (the socalled ochronotic arthropathy). Treatment is symptomatic and some patients, due to severe joint damage and severe pain, require endoprosthetic joint replacement $[7,8]$, which provides only temporary relief. Ongoing clinical trials are investigating nitisinone (an orphan medicine already authorised for the treatment of type 1 tyrosinaemia) in alkaptonuria, and the results are promising [8]

The diagnosis of albinism in its various forms, i.e. as an isolated defect (e.g. ocular albinism) or as an element of a syndrome (e.g. Chediak-Higashi syndrome), requires following certain recommendations on the management and monitoring of the disease.

The Polish nationwide newborn screening programme coordinated by the Institute of Mother and Child enables a rapid 
diagnosis of inborn errors of metabolism and prompt provision of specialist treatment. It is important that specialist care for patients with inborn errors of metabolism is continued both during childhood and adulthood. Furthermore, some inborn errors of metabolism do not become clinically manifest until adulthood, which is why it is particularly important to make appropriate medical care (evaluation and treatment) accessible to these patients.

The aim of our study was to evaluate the Polish public healthcare system in terms of organisation of and accessibility to healthcare services for patients with the disorders of aromatic amino-acid metabolism.

\section{Material and methods}

We used individual reporting data of the Polish National Health Fund (NFZ), i.e. information about the services claimed to the payer by service providers in 2009-2015. Patients with the disorders of aromatic amino-acid metabolism coded as E70 according to the $10^{\text {th }}$ edition of the International Statistical Classification of Diseases and Related Health Problems (ICD-10) were included in the analysis. These disorders include: E70.0 - Classical phenylketonuria, E70.1 - Other hyperphenylalaninaemias. E70.2 - Disorders of tyrosine metabolism (Alkaptonuria, Hypertyrosinaemia, Ochronosis, Tyrosinaemia, Tyrosinosis), E70.3 Albinism (Ocular, Oculocutaneous, Chediak-Higashi syndrome, Cross syndrome, Hermansky-Pudlak syndrome), E70.8 - Other disorders of aromatic amino-acid metabolism (Disorders of: histidine metabolism, tryptophan metabolism), E70.9 - Disorder of aromatic amino-acid metabolism, unspecified.

Our analysis took into account the services provided to patients who first appeared in the public healthcare system in 2009. This was defined as registered incidence. A patient appearing in the NFZ reporting system during this period was considered a new patient (a first-time patient) if they appeared in the system with a given diagnosis for the first time during the period of interest and if the main reason for providing a service was related to a diagnosis within the group of rare metabolic disorders coded as E70.0 to E70.9. Registered prevalence was also assessed, and individuals with a specific disease were defined as all the patients classified as new cases of that specific disease in the public healthcare system since 2009 (with a diagnosis from the analysed group) who were still alive on $31 / 12 / 2015$. In order to reduce the risk of an error related to the change in the initial diagnosis that appeared in the system, we reviewed the treatment history of each patient until their appearance in the system, and the ICD code was overwritten if it had changed during the period of service provision. Information about each patient was coded in the NFZ database of individual services using a unique patient identifier.

In the present analysis, individuals over 18 years of age were included in the adult group, individuals 18 years of age or younger were considered to be children, and patients classified as "neonates" based on Diagnosis Related Groups (DRG codes: N20-N34) were classified as neonates. The age at di- agnosis was calculated using the median age of the patients appearing in the system between 2013 and 2015.

The present analysis has been prepared as part of the mapping of health needs in metabolic disorders published in December 2016. The documents for each province of Poland are available here: http://www.mapypotrzebzdrowotnych. mz.gov.pl/.

Statistical analysis was conducted using R Studio, version 1.0.136. The diagrams provided in this publication were prepared using the RStudio library for data visualisation ggplot2, version 2.1.0, and Microsoft Exce 2013. Some of these diagrams use a logarithmic scale to show the magnitude of the depicted phenomenon in a clearer manner.

\section{Results}

Table I provides registered incidence data for the period from $01 / 01 / 2009$ to $31 / 12 / 2015$. Columns 2 to 8 provide a list of patients who first appeared in the healthcare system in specific years. As data collection started in 2009, the number of patients registered in the healthcare system in that year includes those who first appeared in the system in 2009 and those who first appeared in the previous years. Based on these data, indicators for the entire study population with a specific diagnosis were calculated and presented. The data show a considerable heterogenicity of the patient population and a large number of patients coded in the ICD-10 system without the extension (E70), which makes it difficult to correctly classify these patients.

Figure 1 provides a histogram of the age of patients with conditions falling under the category of the disorders of aromatic amino-acid metabolism who were first registered in the healthcare system in 2009-2015. The largest group of patients appeared in the system at the age of 1 year old, with the number of patients markedly decreasing in the subsequent years. Diagram A represents children and young adults up to 28 years of age. The population of patients aged 0-28 years accounts for $99 \%$ of all the cases, while patients older than 28 years of age constitute a mere one percent of the entire population. The frequency of patients older than 28 years of age who appeared in the healthcare system was zero or close to zero (Diagram B). Patients with the diagnosis of phenylketonuria (E70.0) or other hyperphenylalaninaemias (E70.1) are those that most commonly appear in the healthcare system. Patients over the age of 28 years most commonly appear with the code E70.

Figure 2 shows the number of patients by age who first appeared in the system in 2009-2015 either in outpatient specialist care (AOS) facilities or in hospitals. The largest number of patients (more than 600) was hospitalised in the first year of life, with the number of hospitalisations after the second year of life decreasing to zero. In AOS, the largest number of patients (more than 600) were observed in the first year of life. After the second year of life the number of patients decreases and plateaus until the age of 18 years at about $60-70$ patients in each age group receiving AOS services. After the age of 18 years, 


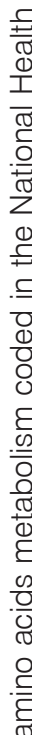

(uе!̣рәш) sц1еәр ло ә6 $\forall$

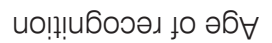

uo!̣ejndod puesnout 00 L ıəd

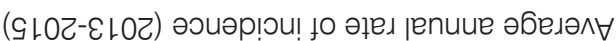

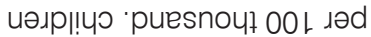

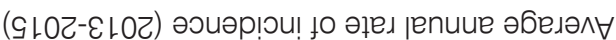

St|npe puesnoul 00 L lad (GLOZ-ELOZ)

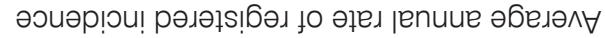

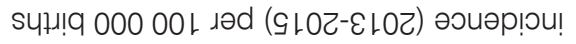

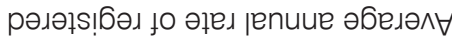

(

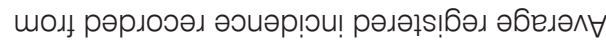

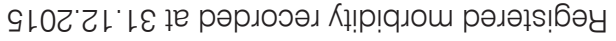

sч1теә

uns

GLOZ

†LOZ

$\varepsilon\llcorner 0 乙$

乙ட0Z

LLOZ

OLOZ

6002

әроว 0เดつ।

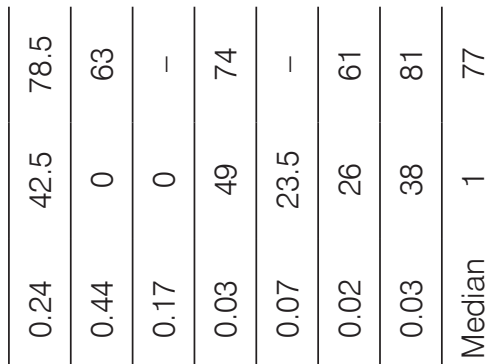

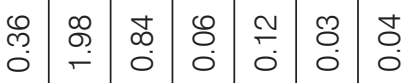

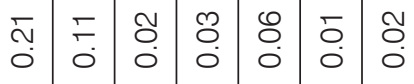

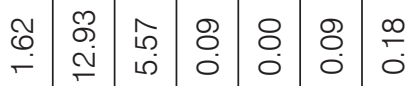

б

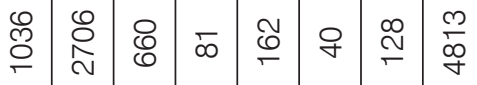

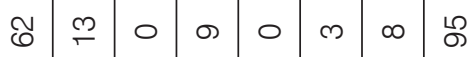

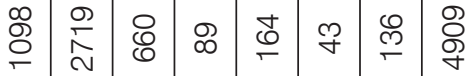



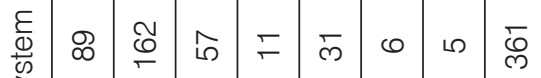

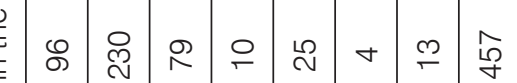

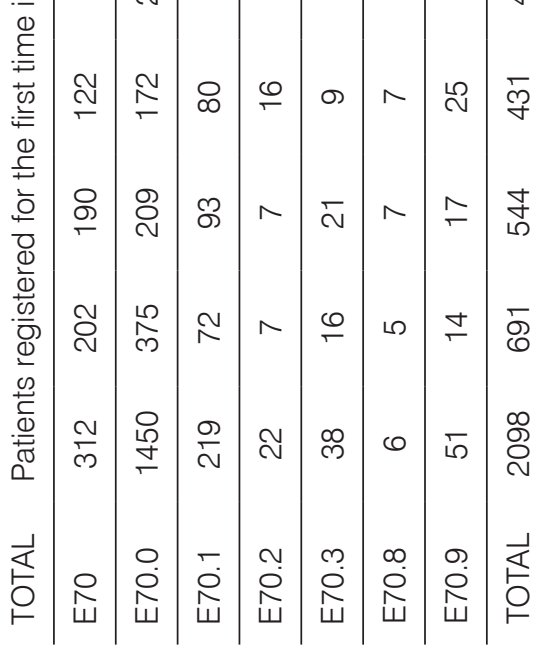



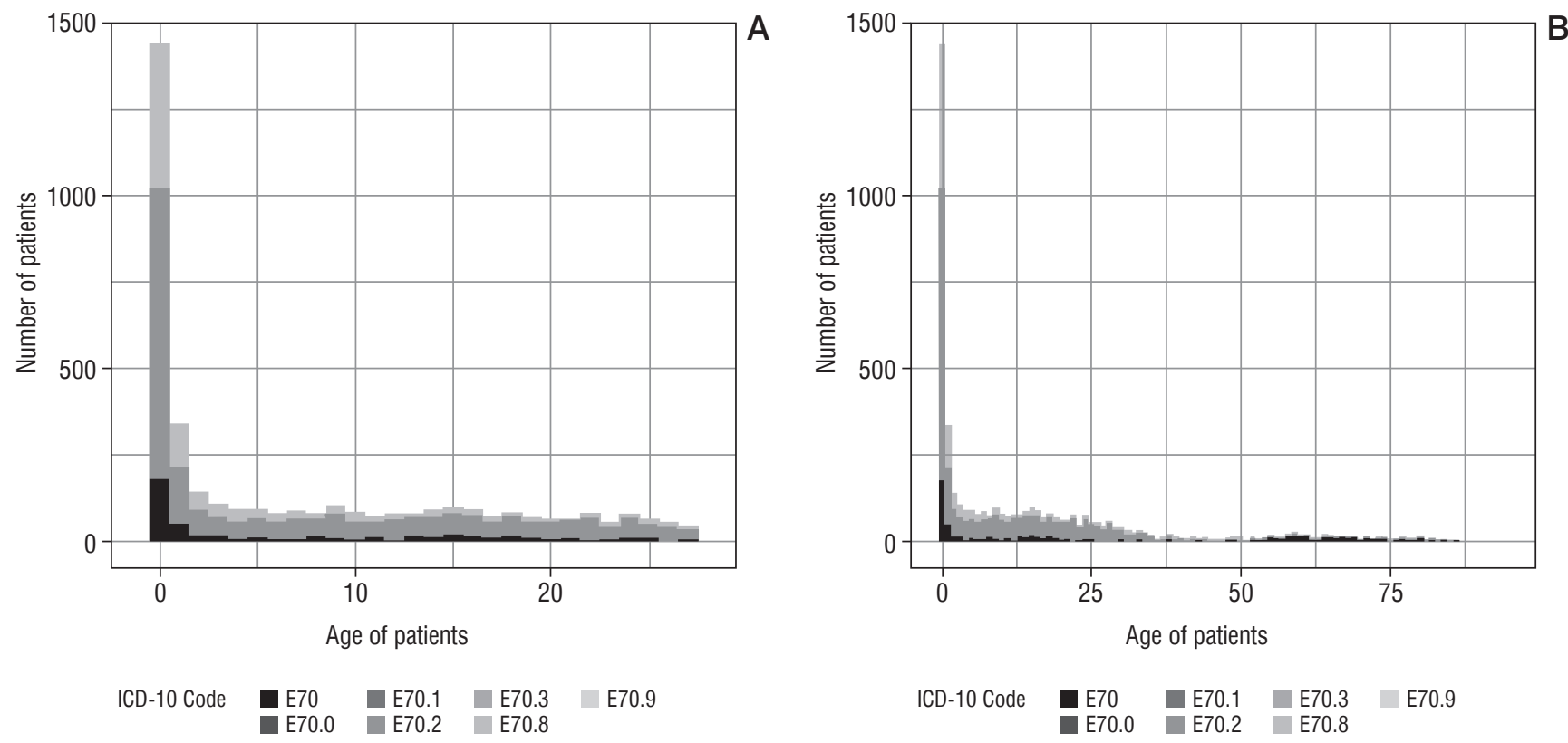

Figure 1. Histogram of age of patients with disorders of aromatic amino acid metabolism coded under the National Health Fund (NFZ) with ICD-10 codes according to the International Classification of Diseases and Health Problems, who appear in the NFZ system in 2009-2015. In graph 1A, 99\% of patients with E70- E70.9 disease were presented on the abscissa axis, while all patients were depicted in graph $1 \mathrm{~B}$
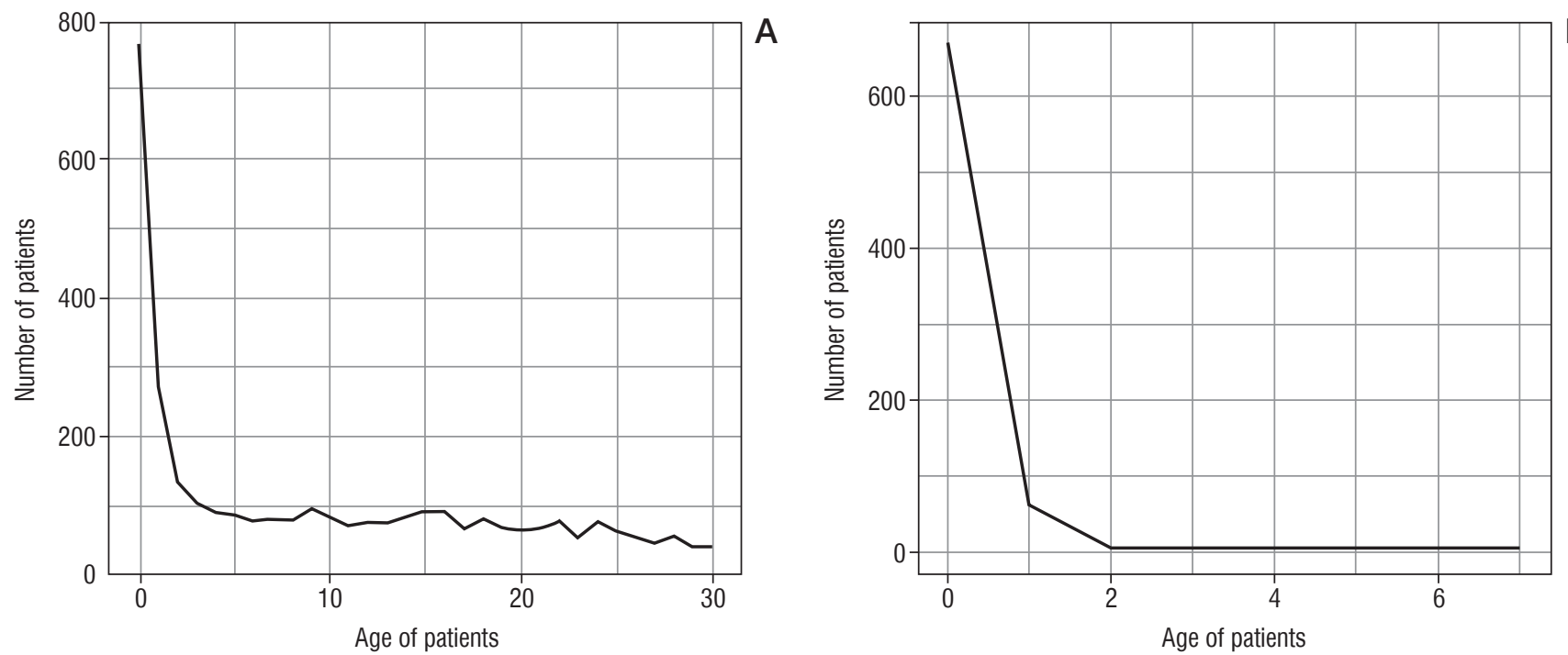

Figure 2. The age chart of patients with disorders of aromatic amino acid metabolism coded under the National Health Fund (NFZ) with codes ICD-10 (E70, E70.1, E70.2, E70.3, E70.8, E70.9) according to International Classification Diseases and Health Problems, who first appear in the NFZ system in 2009-2015. Diagram A - patients in outpatient specialist care (AOS), chart B patients in hospital care 
there is a decreasing number of patients in AOS, with a rapid reduction approaching zero after 28 years of age.

A total of 95 deaths were reported in the entire study population with the mean age of death being 77 years. The largest number of deaths were recorded after the age of 70 years, $21 \%$ of all the deaths occurred in working-age patients and in children (2 deaths). The child with disorder of tyrosine metabolism died at the age of 2 years, while the one with classical phenylketonuria died at 11 years of age. The causes of death were not analysed. The largest number of deaths were recorded in adults with the code E70. There were no deaths of patients with the codes E70.1 and E70.3 (Fig. 3).

\section{Discussion}

This paper is the first one to present an analysis of the Polish public healthcare system in terms of organisation of and accessibility to healthcare services for patients with the disorders of aromatic amino-acid metabolism, based on the individual reporting data of the NFZ, i.e. information about the services claimed to the payer by service providers in 2009-2015.

A total of $22 \%$ of the patients in the study population were coded generally as having a diagnosis of disorders of aromatic amino-acid metabolism: E70 according to the $10^{\text {th }}$ edition of the International Statistical Classification of Diseases and Related Health Problems (ICD-10). The lack of extension in the coding of the data reported to the NFZ makes it impossible to correctly assign these patients to the correct disease entity. Failure to provide the extension in coding may result from the lack of the right diagnosis or from incorrect coding. As the largest number of deaths with a median age of death being 78.5 years were recorded in the group of patients coded as E70, it is reasonable to hypothesise that this group mainly consisted of adult patients very recently diagnosed with phenylketonuria, so without a precisely established form of the disease. Currently, the service providers are not obliged to enter the code along with the extension when reporting to the NFZ.

The largest number of patients were hospitalised and provided with outpatient care in the first year of life. This applies to patients diagnosed with phenylketonuria (classical or mild) in the presymptomatic period by neonatal screening. These results demonstrate the very good organisation of newborn screening in Poland by the Institute of Mother and Child, along with the subsequent monitoring in accordance with the relevant recommendations. Thanks to the launch of mass newborn screening programmes in Poland, it is now possible to provide early diagnosis and treatment to avoid severe mental retardation. The currently available modern molecular testing methods allow to establish the genotype, which may be the grounds for selecting optimal treatment: dietary or pharmacological. It is an example of personalised medicine, which will most likely become medicine of the future. The role of newborn screening in reducing mortality in children and in providing specialist care for patients with inborn errors of metabolism has been emphasised by many authors $[4,9,10]$. Our analysis demon-

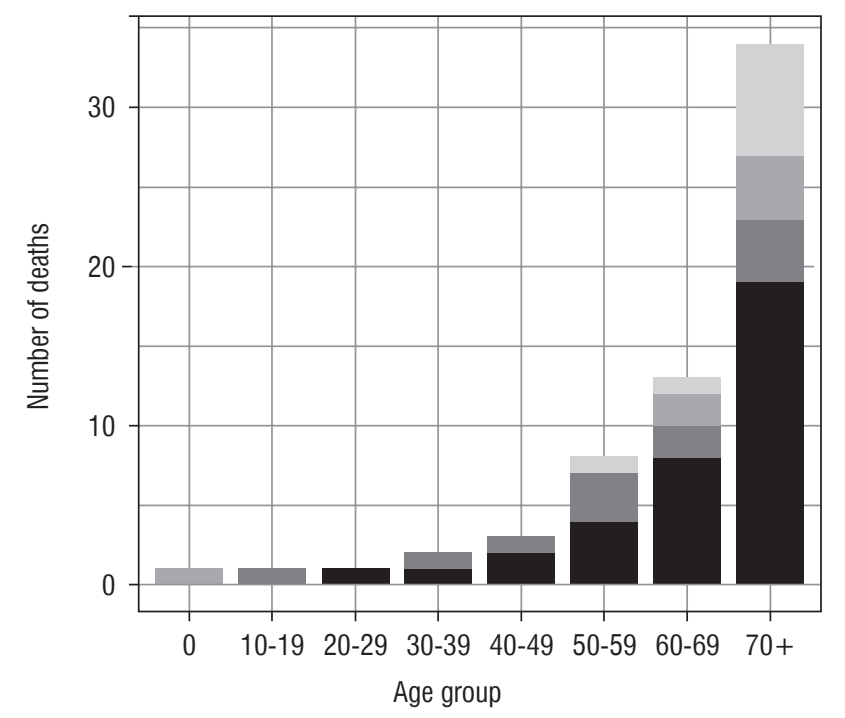

$\begin{array}{cccc}\text { ICD-10 Code } & \text { E70 } & \text { E70.2 } & \text { E70.9 } \\ & \text { E70.0 } & \text { E70.8 } & \end{array}$

Figure 3. Histogram of the age of death of patients with disorders of aromatic amino acid metabolism coded under the National Health Fund (NFZ)

strates that hospitalisations of patients after the second year of life were close to zero, which results from the specific characteristics of some of the disease entities whose treatment only rarely requires hospitalisation. After the second year of life the number of patients remaining in outpatient care decreased and plateaued during the paediatric period below 18 years of age, further decreasing in young adults and rapidly falling close to zero in patients over the age of 28 years. Some of the patients with the disorders of aromatic amino-acid metabolism are known not to require treatment and monitoring can be performed once a year (e.g. in albinism, which reduced the number of patients remaining in outpatient care after the second year of life). The decreasing number of adults being under the care of specialist clinics is worrying. Especially since some disorders, such as alkaptonuria, do not become clinically manifest until adulthood, which is when these patients require appropriate medical care the most.

A total of $55 \%$ of the patients in the study population were affected with classical phenylketonuria (E70.0). This patient group requires ongoing care at the clinic for metabolic disorders. Classical phenylketonuria is an example of a disease in which early diagnosis and low-phenylalanine diet is of key importance for the normal development of the child. Continuing the treatment throughout the patient's lifetime is recommended [11]. Adults who discontinue the low-phenylalanine diet have been confirmed to develop mental, cognitive and emotional disorders $[12,13]$. Treatment must also be used in women of childbearing age. High maternal blood levels of phenylalanine leads to maternal phenylketonuria syndrome consisting of 
microcephaly, intellectual disability, intrauterine growth retardation, congenital anomalies of the cardiovascular, gastrointestinal and skeletal systems [14]. In our study, patients older than 28 years of age constituted a mere one percent of all the patients who received the services of AOS, which points to insufficient outpatient medical care in the group of adult patients. Analysis of data from other countries also shows deficiencies in the care for adult patients with phenylketonuria. In a study by Berry et al. , 71\% adult PKU patients aged 19-45 years were not actively treated by the metabolic clinic [15]. The authors point out that some clinics at paediatric hospitals are not allowed to provide care to adult patients [16], and this is also the case in Poland. In accordance with the European recommendations of phenylketonuria diagnostics and treatment, this care should be carried out by adult metabolic specialists or dedicated people experienced in specialized care for adults with inborn errors of metabolism. In order to assist in continuing treatment of adults with phenylketonuria and other inborn errors of metabolism, the role of transition from paediatric into general care is emphasised $[17,18]$.

In the analysed group of patients with disorders of aromatic amino-acid metabolism, 95 deaths were reported, including $21 \%$ of deaths in patients below the age of 60 years. Two deaths were reported in children, including one in a child diagnosed with disorders of tyrosine metabolism and the other in a child with classical phenylketonuria. The causes of these death were not analysed. The largest number of deaths were recorded in adults older than 70 years of age. The predominance of the code E70 without the extension is notable in those who died after the age of 60 years, which may suggest several causes. These are: the lack of specialist knowledge on the inborn errors of metabolism among doctors specialising in adult medicine and providing care to these patients, the diagnostic difficulties in this group of patients, and, most likely, these are deaths of patients with phenylketonuria who were born before the era of newborn screening programmes for phenylketonuria. The mean age of death among patients with untreated phenylketonuria has been reported in the literature at 55.8 years [19]. In our publication, the mean age of death in patients with phenylketonuria was higher (63 years), although $38 \%$ of deaths were reported in working-age patients, which suggests the need for specialist care in adults. In children with untreated type 1 tyrosinaemia, death usually occurs before the age of 10 years, and the need for rapid diagnosis and early

\section{References}

1. Hagedorn TS, van Berkel P, Hammerschmidt G, et al. Requirements for a minimum standard of care for phenylketonuria: the patients' perspective. Orphanet J Rare Dis 2013; 8: 191. doi: 10.1186/17501172-8-191

2. Trefz F, Maillot F, Motzfeldt K, et al. Adult phenylketonuria outcome and management. Mol Genet Metab 2011; 104 Suppl: S26-S30. doi: 10.1016/j.ymgme.2011.08.025 treatment is emphasised to reduce mortality in this group of patients [20, 21].

A strength of our study is the analysis of all the patients reported to the NFZ in the outpatient and inpatient setting in 2009-2015. A limitation of our study is the impossibility to verify the diagnoses in patients coded as the disorders of aromatic amino-acid metabolism (E70), which could have affected the number of patients in specific groups coded with the extension. We only analysed patients who had been registered in the healthcare system, which does not offer the possibility of assessing the total number of patients. We did not analyse factors affecting the difficulties in following the diagnostic and therapeutic recommendations, such as the costs of treatment. The causes of patient deaths were not analysed.

To summarise, the group of patients with the disorders of aromatic amino-acid metabolism is heterogenous and includes patients who require lifetime treatment and patients who mostly require monitoring. Children in their first year of life required inpatient and outpatient care more often. In AOS, patients with classical phenylketonuria were most commonly reported. This is in line with the current medical practice and the most recent European recommendations on the frequency of clinical, dietary and biochemical monitoring in patients with phenylketonuria provided in the outpatient specialist care [22]. Active outpatient care for adult patients was insufficient. Patients after the age of 28 years constituted a mere $1 \%$ of the patients in AOS. Urgent implementation of systemic solutions in this area is necessary, starting from acquiring essential specialist knowledge on the inborn errors of metabolism among doctors practising adult medicine. A total of $21 \%$ of all the deaths occurred in working-age patients and in children (2 deaths). It is necessary to draw attention to the correct coding of disease entities.

\section{Conclusions}

Neonates, infants, children and adolescents with disorders of amino acid metabolism have been had full access to a wellorganized specialized medical care system in Poland, and were followed throughout the whole postnatal period until $18^{\text {th }}$ year of life. In contrast, an active care for adult patients with the disorders was limited. It is necessary to properly encode the disease by using the ICD-10 extension codes in order to avoid inconsistency in reporting or misdiagnosis.
3. González García MB, Conde-Guzon P, Alcalde Martín C, et al. Neuropsychological assessment among children and adolescents with phenylketonuria and hyperphenylalaninemia and its relationship with plasma phenylalanine levels. Arch Argent Pediatr 2017; 115: 267273. doi: 10.5546/aap.2017.eng.26

4. Giżewska M, MacDonald A, Bélanger-Quintana A, et al. Diagnostic and management practices for phenylketonuria in 19 countries of the South and Eastern European Region: survey results. Eur J Pediatr 2016; 175: 261-272. doi: 10.1007/s00431-015-2622-5 
5. Jarochowicz S, Mazur A. Fenyloketonuria - choroba metaboliczna uwarunkowana genetycznie. Przegląd Medyczny Uniwersytetu Rzeszowskiego 2007; 1: 76-90.

6. Pohorecka M, Biernacka M, Jakubowska-Winecka A, et al. Behavioral and intellectual functioning in patients with tyrosinemia type I. Pediatr Endocrinol Diabetes Metab 2012; 18: 96-100.

7. Arnoux JB, Le Quan Sang KH, Brassier A, et al. Old treatments for new insights and strategies: proposed management in adults and children with alkaptonuria. J Inherit Metab Dis 2015; 38: 791-796. doi: 10.1007/s10545-015-9844-6

8. Sykut-Cegielska J. Alkaptonuria - first inborn error of metabolism known for a century and new treatment option - preliminary report. Dev Per Med 2015; 19: 505-510.

9. Mayorandan S, Meyer U, Gokcay G, et al. Cross-sectional study of 168 patients with hepatorenal tyrosinaemia and implications for clinical practice. Orphanet J Rare Dis 2014; 9: 107. doi: 10.1186/ s13023-014-0107-7

10. Oshima $Y$, Yamamoto $T$, Ishikawa $T$, et al. Postmortem genetic analysis of sudden unexpected death in infancy: neonatal genetic screening may enable the prevention of sudden infant death. J Hum Genet 2017; 62: 989-995. doi: 10.1038/jhg.2017.79

11. Camp KM, Parisi MA, Acosta PB, et al. Phenylketonuria Scientific Review Conference: state of the science and future research needs. Mol Genet Metab 2014; 112: 87-122. doi: 10.1016/j.ymgme.2014.02.013

12. Albrecht J, Garbade SF, Burgard P. Neuropsychological speed tests and blood phenylalanine levels in patients with phenylketonuria: a meta-analysis. Neurosci Biobehav Rev 2009; 33: 414-421. doi: 10.1016/j.neubiorev.2008.11.001

13. Romani C, Palermo L, MacDonald A, et al. The impact of phenylalanine levels on cognitive outcomes in adults with phenylketonuria:
Effects across tasks and developmental stages. Neuropsychology 2017; 31: 242-254. doi: 10.1037/neu0000336

14. Didycz B, Domagała L, Pietrzyk JJ. Zespół fenyloketonurii matczynej - problem nadal aktualny. Przegl Lek 2009; 66: 1-2.

15. Berry SA, Brown C, Grant M, et al. Newborn screening 50 years later: access issues faced by adults with PKU. Genet Med 2013; 15: 591-599. doi: 10.1038/gim.2013.10

16. Burton BK, Leviton L. Reaching out to the lost generation of adults with early treated phenylketonuria (PKU). Mol Genet Metab 2010; 101: 146-148. doi: 10.1016/j.ymgme.2010.06.006

17. Mütze $U$, Roth A, Weigel JF, et al. Transition of young adults with phenylketonuria from pediatric to adult care. J Inherit Metab Dis 2011; 34: 701-709. doi: 10.1007/s10545-011-9284-x

18. Stępień KM, Hendriksz ChJ. The principles of the transition process from paediatric to adult services in inborn errors of metabolism - own experience. Dev Per Med 2015; 19: 523-528.

19. Jancar J. Increased life expectancy in people with untreated phenylketonuria. J Intellect Disabil Res 1998; 42: 97-99.

20. Mitchell GA, Yang H. Remaining Challenges in the Treatment of Tyrosinemia from the Clinician's Viewpoint. Adv Exp Med Biol 2017; 959: 205-213. doi: 10.1007/978-3-319-55780-9 19

21. Sniderman King L, Trahms C, Scott CR. Tyrosinemia Type I. GeneReviews ${ }^{\circledR}$ [Internet]. University of Washington, Seattle 1993-2017. 2006 Jul 24 [updated 2017 May 25].

22. van Wegberg AMJ, MacDonald A, Ahring K, et al. The complete European guidelines on phenylketonuria: diagnosis and treatment. Orphanet J Rare Dis 2017; 12: 162. doi: 10.1186/s13023-017-0685-2 